Ann. Biol. anim. Bioch. Biophys., 1978, 18 (2A), 259-264.

\title{
The pineal gland of the mole (Talpa europaea, L.) V) Activity of hydroxyindole-O-methyl transferase (HIOMT) in the formation of melatonin/5-methoxytryptophol in the eyes and the pineal gland
}

par P. PÉVET ( $\left.{ }^{1}\right)$, M. G. M. BALEMANS *, F. A. M. BARY *, E. M. NOORDEGRAAF *

The Netherlands Institute for Broin Research, Amsterdam and Department of Anatomy and Embryology, University of Amsterdam,

* Zoological Laboratory, Section of Histology and Cell Biology, State University of Utrecht, Utrecht, the Netherlands.

Summary. Using a method in which no substrate is added, the capacity of HIOMT to synthesize melatonin and/or 5-methoxytryptophol has been determined in the pineal and the eyes of the mole, a mammal having an atrophied visual system. In all animals studied, the activity of HIOMT in both eyes taken together was 2-10 times higher than in the pineal. The results prove that the pineal is not the only, and not always the most important, source of methoxyindoles.

\section{Introduction.}

The pineal gland of all mammalian species so far examined is generally rich in serotonin. It also contains smaller quantities of related 5-hydroxy-and methoxyindoles (Quay and Halevy, 1962 ; Quay, 1963, 1974). Melatonin has aroused the greatest interest among scientists. Although present in nervous tissue, retina, Harderian gland, intestine, plasma and urine (Arendt et al., 1975 ; Barchas and Lerner, 1964 ; Bubenik et al., 1976a, b, c, 1977 ; Koslow and Green, 1973 ; Lynch et al., 1975 ; Mull and Ralph, 1972 ; Pang and Ralph, 1975 ; Pang et al., 1973, 1976, 1977 ; Pelham ef al., 1972, 1973 ; Raikhlin ef al., 1975 ; Rollag and Niswender, 1976 ; Vaughan ef al., 1974, 1976), melatonin has always been considered to be essentially a pineal hormone.

In the pineal gland serotonin is converted into $\mathrm{N}$-acetyl serotonin by $\mathrm{N}$-acetylation (Weissbach at al., 1960) while this product is converted by O-methylation (Axelrod

(1) Please send correspondence to : Dr. P. Pevet, The Netherlands Institute for Brain Research, ljdijk 28, Amsterdam-O., The Netherlands. 
and Weissbach, 1960) to melatonin. The two enzymes required for these conversions are $\mathrm{N}$-acetyltransferase (NAT) and hydroxyindole-O-methyl transferase (HIOMT). By other pathways of serotonin metabolism, HIOMT is also involved in the formation of 5-methoxy-tryptophol (Mclsaac ef al., 1965), a compound known to show physiological activity (Mclsaac et al., 1964 ; Balemans, 1974), 5-methoxyindole-3-acetic acid (Lerner et al., 1959) and 5-methoxytryptamine (Quay and Smart, 1967).

Initially, HIOMT was thought to be present only in the pineal gland. Subsequently it was identified in the mammalian retina (Cardinali and Rosner, 1971, 1972 ; Quay, 1965) and in the Harderian gland (Vlahakes and Wurtman, 1972 ; Cardinali and Wurtman, 1972). The presence of HIOMT in the retina is of special inferest. This enzyme has also been found in lower vertebrate pineals (Fenwick, 1970 ; Baker et al., 1965) which, like the retina, contain photoreceptor cells. Moreover it is now proved (Pevet and Collin, 1976 ; Pevet ef al., 1977) that the pinealocytes of mammals belong to a sensory cell line that has evolved from sensory pineal photoreceptors of lower vertebrates during phylogenetic development (Collin, 1969, 1971). Considering that the pinealocytes did evolve from photoreceptor cells, it seemed of interest to study the capacity of HIOMT to synthesize melatonin and/or 5-hydroxytryptophol in the pineal and in the eyes of a mammal possessing an atrophied and rudimentary visual system under natural conditions. The mole (Talpa europaea, L.) is an appropriate animal for such an investigation.

\section{Material and methods.}

Eight moles of both sexes and of different ages were captured in Deux-Sèvres (France) on March, 22, 1977. Immediately after capture these moles were decapitated under ether anesthesia and the pineal and the eyes were quickly removed. The organs were then frozen, transported and conserved in liquid nitrogen until they were investigated.

The details of the method used to determine HIOMT activity are extensively reported and discussed elsewhere (Balemans ef al., submitted for publication).

Using this method, the methylation of several 5-hydroxyindoles in the pineal and in the two eyes was analysed by using the 5-hydroxyindoles present in the tissue studied as a substrate. This implies that no extra substrate was added to the incubation medium ( $20 \mu \mathrm{l}$ of $0.1 \mathrm{M}$ phosphate buffer, $\mathrm{pH} 8.0$ and $10 \mu \mathrm{l}$ of S-adenosylmethionine- ${ }^{3} \mathrm{H}$, $1.5 \mu \mathrm{Ci} / 10 \mu \mathrm{l}$ in $\mathrm{H}_{2} \mathrm{SO}_{4}$, $\mathrm{pH} 2.5$ ). After incubation at $37^{\circ} \mathrm{C}$ for $60 \mathrm{~min}$, thinlayer chromatography was performed with pineal tissue together with the incubation medium. The chromatograms were developed in chloroform : methanol : ammonia 25 p. 100 ( $60: 35: 5$ ). The spots were scraped and counted (liquid scintillation counter Mark I of Nuclear-Chicago) in $75 \mu \mathrm{l}$ ethanol and $10 \mathrm{ml}$ of a scintillation liquid (tolvene $1000 \mathrm{ml}$ POPOP $0.1 \mathrm{~g}$; PPO $5 \mathrm{~g}$; Cab-0. sil $40 \mathrm{~g}$ ). With this technique, 5-methoxytryptophane, 5-methoxytryptamine, 5-methoxyindole-3-acetic acid can be separated as can melatonin and 5-methoxytryptophol which are located on the same spot. Blanks without pineals and/or eyes were included in each series of incubations (see Balemans et al.). The activity present on the identical spots, as the 5-methoxyindoles in the blanks, was subtracted from that of the tissues studied. 


\section{Results.}

In the moles studied, the methylation of both $\mathrm{N}$-acetylserotonin and 5-hydroxytryptophol was measured together (see Material and Methods). As no substrate was, added, the results indicate the presence of the 5-hydroxyindoles $\mathrm{N}$-acetylserotonin and/or 5-hydroxytryptophol, the methylating enzyme HIOMT, and melatonin and/or 5-methoxytryptophol in the pineal and in the eyes.

The number of animals was too small to determine a possible difference in HIOMT activity in the methylation of $\mathrm{N}$-acetylserotonin and/or 5-hydroxytryptophol between young and adult males and females. However, HIOMT activity in both eyes was always 2-10 times higher than that in the pineal (table 1).

\section{TABLE 1}

HIOMT activity in the formation of melatonin and/or 5-methoxytryptophol in the eyes and the pineal of the mole. The results are expressed in DPM (disintegration per min)

\begin{tabular}{|c|c|c|}
\hline & Pineal & 2 Eyes \\
\hline $\begin{array}{l}\text { young male } \ldots \ldots \ldots \ldots \\
\text { young male } \ldots \ldots \ldots \ldots \ldots \\
\text { adult male } \ldots \ldots \ldots \ldots \ldots \\
\text { adult male } \ldots \ldots \ldots \ldots \ldots \\
\text { young female } \ldots \ldots \ldots \ldots \ldots \\
\text { female (not defermined) } \\
\text { adult female } \ldots \ldots \ldots \ldots \\
\text { pregnant female......... }\end{array}$ & $\begin{array}{l}-609 \\
609 \\
452 \\
406 \\
331 \\
159 \\
847\end{array}$ & $\begin{array}{r}742 \\
811 \\
1840 \\
4934 \\
1704 \\
3082 \\
918 \\
2295\end{array}$ \\
\hline
\end{tabular}

\section{Discussion.}

Quay (1974) wrote : "It is probably safe to assume that melatonin occurring in these and other mammalian tissues and fluid (the peripheral nerves, blood and urine) is derived from the pineal gland, because of the pineal localization of the enzyme responsible for the last step in melatonin's biosynthesis, and because of the above cited loss of melatonin from chicken serum after pinealectomy. There is no evidence as yet that the low levels of this enzyme, hydroxyindole-O-methyltransferase, detectable in retina and Harderian gland can contribute to a release of melatonin from these other tissues. "Bubenik ef al. $(1976 a, b, c, 1977)$ however, on the basis of immunocytological investigations, concluded that the pineal was probably not the only source of methoxyindoles. The results obtained in the mole demonstrate clearly that in a mammal, an extra-pineal biosynthesis of methoxyindoles indeed occurs. Moreover, the results also prove for the first time that the pineal is not always the organ in which most of this compound is synthesized. These observations seem to be of importance especially when considering the paradoxical effects of melatonin reported by different authors. In mammals, melatonin is generally considered to 
exert an antigonadotropic effect (for ref., see Kappers, 1976). Inhibition of the antigonadotropic influence of the pineal by this methoxyindole has, however, also been observed (Reiter et al., 1975). Moreover, although many reports assume or imply only direct effects of administered melatonin, the nervous system and humoral routes are gradually receiving more attention. Quay (1974) and Pavel ef al. (1973) suggested that melatonin may act within the pineal gland itself to influence the secretion of pineal antigonadotropic compounds (peptides or polypeptides?). On the other hand, it has also been demonstrated (Hoffman and Küderling, 1977 ; Turek, 1977) that, after pinealectomy, an antigonadotropic activity of exogenous melatonin is observed. This proves that this antigonadotropic effect was not due to any change in synthesis of pineal peptides or any other compounds secreted by the pineal.

The production of methoxyindoles in different organs, as has now been demonstrated in the mole, could perhaps help in understanding the paradoxical endocrinological effects of melatonin. The methoxyindoles produced by the pineal cells could possibly act in these cells, while those produced by other organs could act via the bloodstream either on the pineal or on its target organs. Another possibility is that the methoxyindoles synthesized in the pineal may differ from those synthesized at ofher sites.

With the technique used, it has been impossible in the mole to separate the action of HIOMT in forming melatonin from that of its 5-methoxytryptophol-forming role. Other investigations, now in progress, will permit to determine whether there is a possible difference between the eyes and the pineal in the quantitative distribution of these two methoxyindoles.

As a high HIOMT activity has been demonstrated in the atrophied eyes of the mole, the question arises whether this observation can be related to the fact that the mole retina is rudimentary. Only future research with other fossorial blind mammals can answer this question.

Reçu en novembre 1977. Accepté en décembre 1977.

Acknowledgments. - The authors wish to thank Prof. Dr. J. Ariëns Kappers for revising the paper, and Miss J. Sels for typing the manuscript.

Résumé. L'activité de l'HIOMT dans la synthèse de la mélatonine et/ou du 5-méthoxytryptophol a été étudiée dans la pinéale et les yeux de la Taupe, un Mammifère possédant un appareil visuel atrophié. Dans tous les spécimens étudiés, il a été démontré que l'activité de l'HIOMT dans les yeux était de 2 à 10 fois supérieure à celle observée dans la pinéale. Ces résultats qui prouvent que la pinéale n'est pas toujours le seul et le plus important lieu de synthèse des méthoxyindoles, ont été discutés.

\section{References}

ARENDT J., PAUNIER L., SIZONENKO P. C., 1975. Melatonin radioimmunoassay. J. clin. Endocr. Mefab., 40, 347-350.

AXELROD J., WEISSBACH H., 1960. Enzymatic O-methylation of $\mathrm{N}$-acetyl-serotonin to melatonin. Science, 131, 1312. 
BAKER P. C., QUAY W. B., AXELROD J., 1965. Development of hydroxy-indole-O-methyl transferase activity in eye and brain of the amphibian, Xenopus laevis. Life Sci., 4, 1981-1987.

BALEMANS M. G. M., 1974. The pineal gland. A study on the presence and the biological significance of melatonin and 5-methoxytryptophol. Thesis, Utrecht.

BALEMANS M. G. M., NOORDEGRAAF E. M., BARY F. A. M., Van BERLO M. F. Estimation of the methylating capacity of the pineal gland. With special reference to indole metabolism (submitfed for publication).

BARCHAS J. D., LERNER A. B., 1964. Localization of melatonin in the nervous system. J. Neurochem., 11, 489-491.

BUBENIK G. A., BROWN G. M., GROTA L. J., 1976a. Immunohistological investigations of $\mathrm{N}$-acetylserotonin (NAS) in the cerebellum after parachlorophenylalanine (PCPA) treatment. Experientia, 32, 579-580.

BUBENIK G. A., BROWN G. M., GROTA L. J., 1976b. Immunohistological localization of melatonin in the rat Harderian gland. J. Histochem. Cyfochem., 24, 1173-1177.

BUBENIK G. A., BROWN G. M., GROTA L. J., 1976c. Differential localization of N-acetylated indolealkylamines in CNS and the Harderion gland using immunohistology. Brain Res., 118, 417-427.

BUBENIK G. A., BROWN G. M., GROTA L. J., 1977. Immunohistological localization of melatonin in the rat digestive system. Experimentia, 33, 662-663.

CARDINALI D. P., ROSNER J. M., 1971. Retinal localization of the hydroxyindole-O-methyltransferase (HIOMT) in the rat. Endocrinology, 89, 301-303.

CARDINALI D. P., ROSNER J. M., 1972. Ocular distribution of hydroxy-indole-O-methyltransferase (HIOMT) in the duck (Anas platyrhinchos). Gen. Comp. Endocrinol., 18, 407-409.

CARDINALI D. P., WURTMAN R. J., 1972. Hydroxyindole-O-methyl transferase in rat pineal, retina and Harderian gland. Endocrinology, 91, 247-252.

COLLIN J. P., 1969. Contribution à l'étude de l'organe pinéal. De l'épiphyse sensorielle à la glande pinéale : modalités de transformation et implications fonctionnelles. Ann. Stat. Biol. de Besseen-Chandesse, Suppl. 1, 1-359.

COLLIN J. P., 1971. Differentiation and regression of the cells of the sensory line in the epiphysis cerebri, 79-120. In WOLSTENHOLM G. E. W., KNIGHT J., The pineal gland, CIBA Found. Symp., Churchill, Livingstone.

FENWICK J. C., 1970. Demonstration and effect of melatonin in fish. Gen. Comp. Endocrinol., 14, 86-97.

HOFFMAN K., KUDERLING I., 1977. Antigonadal effects of melatonin in pinealectomized Djungarian hamsters. Naturwissenschaften, 64S, 339-340.

KAPPERS J. ARIËNS, 1976. The mammalian pineal gland, a survey. Acta neurochirurgica, 34, 109149.

KOSLOW S. H., GREEN A. R., 1973. Analysis of pineal and brain indole alkylamines by gas chromatography-mass spectrometry. Adv. biochem. Psychopharmac. 7, 33-43.

LERNER A. B., CASE J. D., BIEMANN K., HEINZELMAN R. V., SZMUSZKOVICZ J., ANTHONY W. C., KRIVIS A., 1959. Isolation of 5-methoxyindole-3-acetic acid from bovine pineal glands. J. am. Chem. Soc., 81, 5264.

LYNCH H. J., WURTMAN R. J., KOSKOWITZ M. A., ARCHER M. C., HO M. H., 1975.

Daily rhythm in human urinary melatonin. Science, N. Y., 187, 169-171.

McISAAC W. M., FARRELL G., TABORSKY R. G., TAYLOR A. N., 1965 . Indole compounds : Isolation from pineal tissue. Science, 148, 102-103.

McISAAC W. M., TABORSKY R. G., FARRELL G., 1964. 5-Methoxytryptophol : effect on estrus and ovarian weight. Science, 145, 63-64.

MULL D., RALPH C. L., 1972. A lightening factor in chicken retinae. Am. Zoologist, $12,674$.

PANG S. F., BROWN G. M., GROTA L. J., CHAMBERS J. W., RODMAN R. L., 1977. Determination of $\mathrm{N}$-acetylserotonin and melatonin activities in the pineal gland, retina, harderian gland, brain and serum of rats and chickens. Neuroendocrinologr, 23, 1-13.

PANG S. F., BROWN G. M., GROTA R. L., RODMAN R. L., 1976. Radioimmunoassay of melatonin in pineal glands, harderian glands, retinas and sera of rats or chickens. Fed. Proc., Fed. am. Soc. exp. Biol., 35, 691. 
PANG S. F., RALPH C. L., 1975. Pineal and serum melatonin at midday and midnight following pinealectomy or castration in male rats. J. exp. Zool., 193, 275-280.

PANG S. F., RALPH C. L., REILLY D. P., 1973. Melatonin in the chicken brain : its origin, diurnal variation, and regional distribution. Gen. comp. Endocr. 22, 499-506.

PAVEL S., DUMITRU I., KLEPSH I., DORCESCU M., 1973. A gonadotropin inhibiting principle in the pineal of human fetuses. Neuroendocrinology, 13, 41-46.

PELHAM R. W., RALPH C. L., CAMPBELL I. M., 1972. Mass spectral identification of melatonin in blood. Biochem. biophys. Res. Comm., 46, 1236-1241.

PELHAM R. W., VAUGHAN G. M., SANDOCK K. L., VAUGHAN M. K., 1973. Twenty-fourhour cycle of a melatonin-like substance in the plasma of human males. J. clin. Endocrin. Metab., 37, 341-344.

PEVET P., COLLIN J. P., 1976. Les pinéalocyłes de Mammifère : Diversiłé, homologies, origine. Etude chez la Taupe adulte (Talpa europaea L.). J. Ultrastruct. Res., 57, 22-31.

PEVET P., ARIËNS KAPPERS J., VOÛTE A. M., 1977. Morphologic evidence for differentiation of pinealocytes from photoreceptor cells in the adult noctule bat (Nyctalus noctula, Schreber). Cell Tiss. Res., 182, 99-109.

QUAY W. B., 1963. Circadian rhythm in rat pineal serotonin and its modifications by estrous cycle and photoperiod. Gen. comp. Endocrinol., 3, 473-479.

QUAY W. B., 1965. Retinal and pineal hydroxyindole-O-methyltransferase activity in vertebrates. Life Sci., 4, 983-991.

QUAY W. B., 1974. Pineal chemistry. Charles V. Thomas, Springfield (U.S.A.).

QUAY W. B., HALEVY A., 1962. Experimental modification of the rat pineal's content of serotonin and related indole amines. Physiol. Zool., 35, 1-7.

QUAY W. B., SMART L. T., 1967. Substrate specificity and post-mortem effects in mammalian pineal acetylserotonin methyltransferase activity. Arch. int. Physiol. Biochim., 75, 197-210.

RAIKHLIN N. T., KVETNOY I. M., TOLKACHEV V. N., 1975. Melatonin may be synthesized in enterochromaffin cells. Nature, Lond., 225, 344-345.

REITER R. J., VAUGHAN M. K., WARING P. J., 1975. Studies on the minimal dosage of melatonin required to inhibit pineal antigonadotropic activity in male golden hamster. Hormone Res., 6, 258-267.

ROLLAG M. D., NISWENDER G. D., 1976. Radioimmunoassay of serum concentrations of melatonin in sheep exposed to différent lighting regimens. Endocrinology, 98, 482-489.

TUREK F. W., 1977. Antigonadal effect of melatonin in pinealectomized and intact male hamsters. Proc. Soc. exp. Biol. Med., 155, 31-34.

VAughan G. M., Pelham R. W., PANG S. F., LaUghlin L. L., VAughaN M. K., 1974. Influence of altered light and sleep cycles on plasma melatonin and urine 5-HIAA in youg men. Endocrinology, Suppl. 94, 311.

VAUGHAN G. M., PELHAM R. W., PANG S. F., LAUGHLIN L. L., WILSON K. M., SANDOCK K. L., VAUGHAN M. K., KOSLOW S. H., REITER R. J., 1976. Nocturnal elevation of plasma melatonin and urinary 5-hydroxy-indeoleacetic acid in youg men : attempts at modification by brief changes in environmental lighting and sleep by autonomic drugs. J. clin. Endocr. Metab., 42, 752-764.

VLAHAKES G. J., WURTMAN R. J., 1972. A Mg²-dependent hydroxyindole-O-methyltransferase in rat Harderian gland. Biochem. biophys. Acta, 261, 194-198.

WEISSBACH H., REDFIELD B. G., AXELROD J., 1960. Biosynthesis of melatonin. Enzymatic conversion of serotonin to $\mathrm{N}$-acetylserotonin. Biochim. biophys, Acfa, 43, 352-353. 